\title{
Knowledge and Awareness of Presence of Microgap at the Implant Abutment Interface and the Use of Sealing Agents Among Dentists
}

\author{
Asha S Hariharan ${ }^{1}$, Deepak Nallaswamy ${ }^{2}$, Subhabrata Maiti ${ }^{3}$ and \\ Asha S Hariharan ${ }^{4}$ \\ ${ }^{1}$ Post Graduate student Dept. Of. Prosthodontics Saveetha Dental College Chennai, India \\ ${ }^{2}$ Director of Academics Saveetha Dental College Chennai, India \\ ${ }^{3}$ Assistant Professor Saveetha Dental College Chennai, India \\ ${ }^{4}$ Post Graduate student Saveetha Dental College Chennai, India, 600077
}

\section{ABSTRACT}

The study aims to evaluate the knowledge and awareness of the presence of micro gaps at the Implant Abutment Interface (IAI) and the use of various sealing agents among dentists. The study was conducted all over India among dentists and dental students using an online questionnaire assessing their knowledge on the subject.Descriptive statistics followed by the Chi-square test were used to describe the association of the results obtained from the survey.The responses to the survey showed that the awareness regarding the presence of a micro gap at the IAI was quite significant among dentists and so was the knowledge regarding the consequences of micro gap at IAI. It also revealed that there was moderate to poor awareness regarding the various sealing agents available and their clinical protocols and indications. Awareness regarding the presence of micro gaps at the IAI showed a positive association with the practitioner group. The awareness of the presence of micro gaps at the IAI is quite high among general dentists. But the awareness of various sealing agents like gap seal and 0-ring and the clinical steps associated with their use seems to be lacking

KEY WORDS: IMPLANT ABUTMENT INTERFACE, IAI, SEALING AGENTS, GAP SEAL, MICRO GAP, O-RING.

\section{INTRODUCTION}

For over 35 years implants have proved to be a promising option as a fixed replacement for missing teeth(Rismanchian et al., 2012). Implant systems consist of an endosteal fixture that Osseo integrates with

\section{ARTICLE INFORMATION}

*Corresponding Author: hariharan.asha00@gmail.com Received 17th June 2020 Accepted after revision 10th August 2020 Print ISSN: 0974-6455 Online ISSN: 2321-4007 CODEN: BBRCBA

Thomson Reuters ISI Web of Science Clarivate Analytics USA and Crossref Indexed Journal

\section{Clarivate}

NAAS Journal Score 2020 (4.31) SJIF: 2020 (7.728)

A Society of Science and Nature Publication,

Bhopal India 2020. All rights reserved.

Online Contents Available at: http//www.bbrc.in/

Doi: http://dx.doi.org/10.21786/bbrc/13.7/15 the bone and a trans mucosal connection (abutment) supported restoration that is screwed on to the fixture(Binon, 2000). Two staged implant processes help minimize early exposure to stress and aids in obtaining osseointegration(Nakahara et al., 2017). The implant abutment connection for a two-piece implant system can be of two types; External connection or Internal connection (Hagiwara and Carr, 2015). External connection comes with an increased vulnerability to off axial loads due to short and narrow geometry leading to deformation of IAI(Gracis et al., 2012). Compared to external connection, internal connection lowered the rotation centre, improved mechanical stability and also 
reduced marginal bone loss when incorporated with platform switching(Sailer et al., 2009).

Misfit in two-piece implants at the IAI is unavoidable due to precision limits during production(Alves et al., 2016). This could lead to micro motion at the interface and could lead to accumulation of bacteria which acts as a challenge for implant success. Gaps and hollow spaces at the IAI act as bacterial reservoirs and are predisposing factors for peri-implantitis which is one of the major challenges to implant success.(Nayak et al., 2014) Peri implantitis results in marginal bone loss, recession and compromised esthetics and in worse case scenarios implant failure.

To seal the gap, various sealing agents are available. These include Gap seal (Hagerwerken, Duisburg, Germany), 0-ring (ORMC0, Milan, Italy), Berutemp 500 T2, Kiero Seal. Sealing agents in the gel form flow better due to the low viscosity sealing the interface efficiently than the 0-ring. (Podhorsky et al., 2016) Knowledge regarding the presence of microgap at the implant abutment interface, and its consequences best enables the dentist to incorporate measures to limit the sequelae that follows when microgap is present at the IAI. To provide a hermetic seal at the IAI in a two-piece implant may not be possible(Quirynen et al., 1994) however incorporation of a sealing agent reduces the bacterial leakage to a great extent. Hence this study aims to evaluate the knowledge and awareness regarding the presence of microgap at IAI and the use of sealing agents among dentists.

\section{MATERIAL AND METHODS}

A cross- sectional electronic questionnaire survey was conducted among dentists all over India in the month of January 2020.The questionnaire was designed in a way to assess the knowledge and awareness regarding the presence of micro gap at the IAI, it's possible complications and the commercially available sealing agents. The survey forms were generated on an online platform Google Docs (Google Business Suite) and were circulated using various social media platforms to over 150 dentists. The survey comprised 13 close ended questions and 2 open ended questions formulated to be wholesome, and assessing the general academic as well as clinical knowledge of the practitioners in the field of implantology specifically implantitis and the factors affecting it. The content of the questionnaire and the phrasing of the questions were discussed and pre-tested among the staff and postgraduate students "?". The questions in the survey fell into broad categories such as:

Demographic data: Data including name, age group, and the level of dentistry practiced ranging from undergraduate students to Prosthodontists and Implantologists.

Knowledge and awareness: Questions assessing the knowledge regarding the presence of microgap, the factors related to it, the normal values of this microgap were assessed using a combination of 'yes' or 'no' and multiple-choice questions. The awareness regarding the presence of various sealing agents was also assessed with a combination of open and close ended questions.

Questions were explained whenever necessary, and assurance of confidentiality of their identities was given. Guidelines followed were as per the Helsinki declaration(World Medical Association Declaration of Helsinki: Ethical Principles for Medical Research Involving Human Subjects, 2004). All the collected data were analyzed using SPSS version 20 (SPSS, IBM, Chicago, USA). Association of knowledge and awareness regarding presence of microgap and sealing agents was made between the different practitioner groups using Chi-square test. The statistically significance level was set at $<0.05$ with a confidence interval of $95 \%$.

\section{RESULTS AND DISCUSSION}

A total of 120 dentists responded to the survey majority of whom belonged to the age group of 20-30 years (77.5\%) (Table 1). The dentists who responded consisted mainly of post graduate students in prosthodontics (20.8\%), PG students in the departments of periodontics, Surgery and implantology (25\%) and general practitioners (17.5\%) (Table 1). Majority of dentists are aware of the presence of microgap at the IAI, $(84.2 \%)$ and consider acceptable micro gap to be 2-4 microns (49.2\%) (fig 4). The major factor that determines the extent of gap at the IAI, according to most dentists, was the geometry of contact area $(42.5 \%)$, followed by the force used to tighten the abutment (27.5\%). 73.3\% of the dentists are aware of the consequences of the microgap at the IAI interface and consider peri- implantitis and marginal bone loss as the major consequences.

The dentists who responded to the survey considered the microgap to be minimum in internal connection as compared to external connection. The awareness regarding the availability of various sealing agents was significant among the dentists (50\%), and the most familiar agent among them was Gap seal. While the dentists were aware of the use of Gap seal at the IAI and considered peri implantitis as a major indication, there was a significant lack of knowledge regarding the clinical steps associated with it. There was moderate awareness regarding the use of 0-ring as an alternative agent for sealing the gap at the IAI (54.2\%). Dentists who answered the survey also favored Gap seal over 0-ring as a better alternative to control the complications associated with the presence of microgap at the implant abutment interface. Association between the practitioner group and the awareness regarding the presence of microgap at the IAI showed a positive association ( $p$ value $=0.014$ ) (fig 1 ). Similar correlation was also observed with awareness of 0 -ring in different practitioner groups ( $p$ value $=0.005$ ) (Table 2). No such significant association was found for general awareness of sealing agents, specifically for gap seal. (Fig2)

The key objective of this survey was to raise awareness among clinicians regarding the presence of microgap 
at the IAI in two-piece implants, its consequences, and measures to prevent these sequelae. This is of utmost importance as it is almost impossible to create a hermetic seal at the IAI, which could lead to microbial leakage that opens doors to the major complications encountered in implant dentistry(Garrana et al., 2016).

Figure 1: Graph shows the awareness of presence of micro gap among different practitioner groups

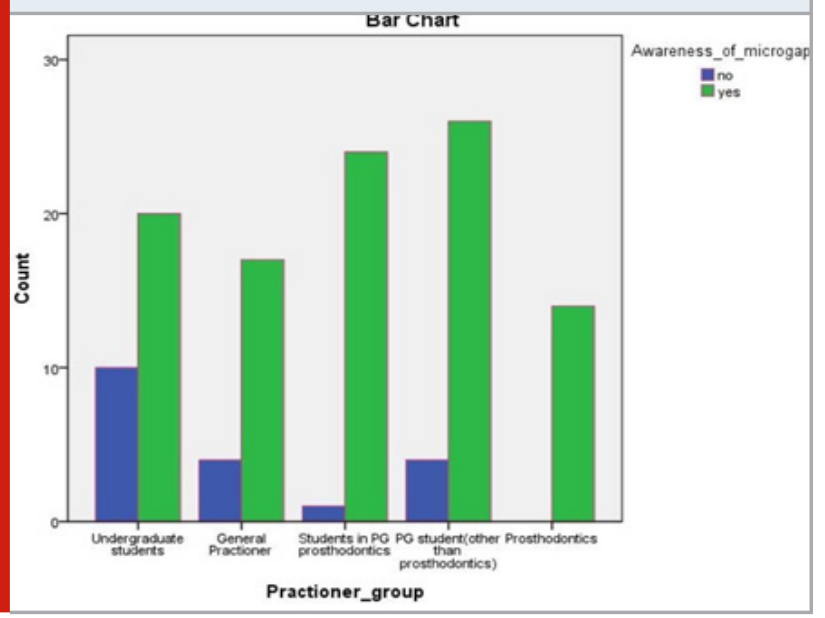

Figure 2: Awareness of sealing agents among different practitioner group

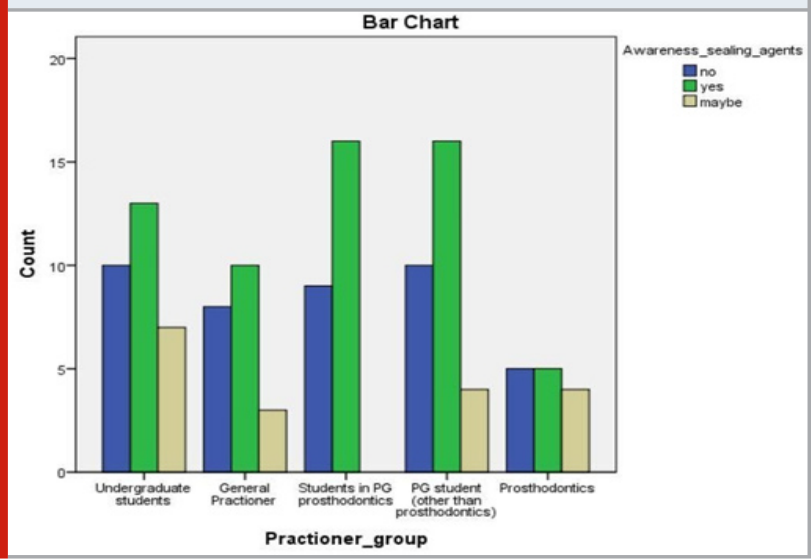

Figure 3: Shows awareness of Gap seal among different practitioner groups

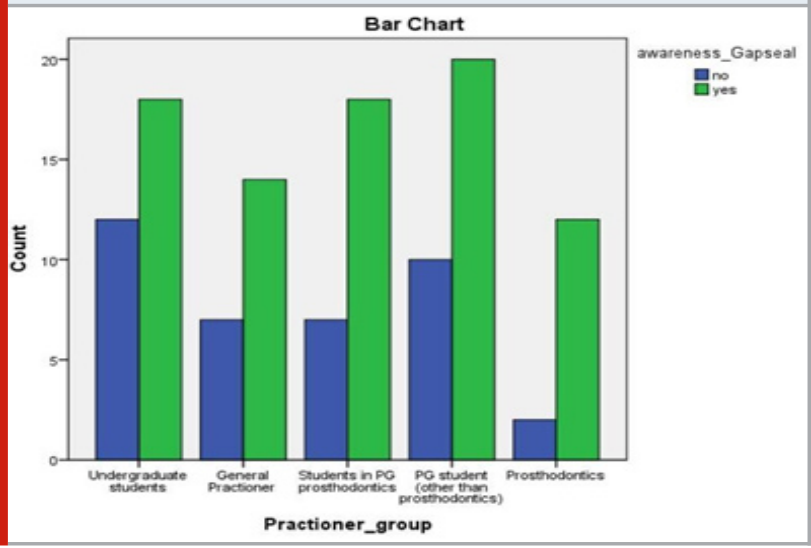

Microgap at IAI: The microgap at the IAI could range from anywhere between $0.1 \mu \mathrm{m}-50 \mu \mathrm{m}$ (Nascimento et al., 2014)(Turkyilmaz et al., 2017) and this depends on geometry of contact area, the type of connection, the abutment material and the force used to secure the abutment . In a study done by Verdugo CL et al., a gap of $10 \mu \mathrm{m}$ was presented by an external connection implant which was more than Morse taper implants with a gap of 2-3 $\mu \mathrm{m}$ (Verdugo et al., 2014). Mangano and his colleagues revealed that the use of Morse taper internal hex connection minimized the IAI gaps and increased mechanical stability which eventually reduced crestal bone loss and prosthetic complications(Mangano et al., 2009). Furthermore, the use of platform switching abutments keeps the microleakage and micromotion at the IAI distant from the alveolar ridge(Canullo et al., 2011; Wang et al., 2015).

In terms of the material used for an abutment Smith NA et al, showed that titanium abutments showed smaller microgap $(2 \mu \mathrm{m})$ as compared to zirconia

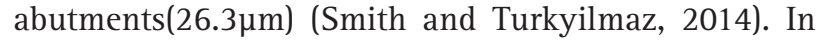
a similar study, RismanchianM et al found that pre machined $\mathrm{Ti}$ abutments showed lesser microgap in comparison to castable abutments, and this was attributed to the lack of precision in finishing and polishing of the custom abutments.(Rismanchian et al., 2012)There is also an observed decrease in microleakage when a torque force of $30 \mathrm{Ncm}$ or more is used, (Verdugo et al., 2014) as there is friction locking at the connection (Olin, 2006). This survey showed a clear understanding among most of the dentists regarding the presence of microgap at the IAI, that it is unavoidable, could range from $2-4 \mu \mathrm{m}$, and that most of them considered the geometry of the contact area as a major factor that determines the microgap. They also considered the internal connection to have a minimal gap at IAI.

Microleakage at IAI: In a five year study conducted by Canullo et al, in humans, for different implant connections under functional loading, showed less bacterial leakage in the internal connection than external connection.(Canullo et al., 2011) Similar conclusions were made in a study done by Koutouzis $\mathrm{T}$ et al.(Koutouzis et al., 2014) The influence of dynamic loading on microleakage was studied by Hermann et al (Hermann et al., 2001) and the study concluded that dynamic loading increases the penetration of bacteria as there was micro movement at the IAI which causes a pumping effect and this leads to detrimental effects on the marginal bone stability. Contrary to these, studies done by Ranieri $\mathrm{R}$ et al.,(Ranieri et al., 2015),Guerra E et al(Guerra et al., 2016) showed there was no significant difference in microleakage in internal and external connection.

Sealing agents: Sealing agents were developed to minimize the microgap at IAI, and are available in various forms. Materials such as 1\% chlorhexidine(D'Ercole et al., 2009; Guerra et al., 2016), Composites(do Nascimento et al., 2017), Gutta Percha, tetrafluoroethylene tapes (Cavalcanti et al., 2016) have been used as sealing agents and showed reasonable closure of space. An interesting 
concept of "chemical locking" was described by Selato et al (Seloto et al., 2018) where he used resins with mono components, without solvents, that polymerize at room temperature in the absence of oxygen, when trapped between the parts.

\begin{tabular}{|c|c|c|c|}
\hline S.no & Question & Options & Frequency (\%) \\
\hline 1. & Age & $\begin{array}{l}\text { 20-30years } \\
\text { 30-40years } \\
\text { 40-50years }\end{array}$ & $\begin{array}{c}93(77.5 \%) \\
19(15.8 \%) \\
8(6.7 \%)\end{array}$ \\
\hline 1 & $\begin{array}{l}\text { Which of the practitioner } \\
\text { groups do you belong to? }\end{array}$ & $\begin{array}{l}\text { Undergraduate students } \\
\text { General practitioner } \\
\text { Student in PG prosthodontics } \\
\text { PG student (other than } \\
\text { prosthodontics) }\end{array}$ & $\begin{array}{c}30(25 \%) \\
21(17.5 \%) \\
25(20.8 \%) \\
30(25 \%)\end{array}$ \\
\hline 2 & Type of implant preference? & $\begin{array}{l}\text { Prosthodontist } \\
\text { one-piece implant } \\
\text { two-piece implant }\end{array}$ & $\begin{array}{l}14(11.7 \%) \\
28(23.3 \%) \\
92(76.7 \%)\end{array}$ \\
\hline 3 & $\begin{array}{c}\text { Are you aware of the micro gap } \\
\text { present at the implant } \\
\text { abutment interface? }\end{array}$ & $\begin{array}{l}\text { No } \\
\text { Yes }\end{array}$ & $\begin{array}{l}19(15.8 \%) \\
101(84.2 \%)\end{array}$ \\
\hline 4 & $\begin{array}{l}\text { How much gap at the implant } \\
\text { and abutment interface would } \\
\text { you consider to be normal? }\end{array}$ & $\begin{array}{l}\text { Less than } 1 \\
\text { micrometer } \\
\text { 1-2 micrometer } \\
\text { 2-4micrometer } \\
>5 \text { micrometer }\end{array}$ & $\begin{array}{c}18(15 \%) \\
33(27.5 \%) \\
59(49.2 \%) \\
10(8.3 \%)\end{array}$ \\
\hline 5. & $\begin{array}{l}\text { What are the factors that } \\
\text { according to you determine } \\
\text { the gap at implant } \\
\text { abutment interface? }\end{array}$ & $\begin{array}{c}\text { Implant system } \\
\text { Geometry of contact } \\
\text { area at IAI } \\
\text { Amount of force used to } \\
\text { tighten the abutment } \\
\text { others }\end{array}$ & $\begin{array}{c}27(22.5 \%) \\
51(42.5 \%) \\
33(27.5 \%) \\
9(7.5 \%)\end{array}$ \\
\hline 6 & $\begin{array}{l}\text { Are you aware of the } \\
\text { consequences of presence } \\
\text { micro gap at the implant- } \\
\text { abutment interface? }\end{array}$ & $\begin{array}{c}\text { No } \\
\text { Yes } \\
\text { Maybe }\end{array}$ & $\begin{array}{l}15(12.5 \%) \\
88(73.3 \%) \\
17(14.2 \%)\end{array}$ \\
\hline 7 & $\begin{array}{l}\text { What do you think are the } \\
\text { consequences of micro gaps } \\
\text { at implant abutment interfaces? }\end{array}$ & $\begin{array}{l}\text { Periimplantitis } \\
\text { Marginal } \\
\text { Bone Loss Both }\end{array}$ & $\begin{array}{l}47(39.2 \%) \\
34(28.3 \%) \\
39(32.5 \%)\end{array}$ \\
\hline 8 & $\begin{array}{l}\text { In what connection do you } \\
\text { think the microgap at } \\
\text { IAI is minimum? }\end{array}$ & $\begin{array}{l}\text { Internal connection } \\
\text { External Connection }\end{array}$ & $\begin{array}{c}96(80 \%) \\
24(20)\end{array}$ \\
\hline 9 & $\begin{array}{c}\text { Are you aware of various } \\
\text { sealing agents used to control }\end{array}$ & $\begin{array}{l}\text { No } \\
\text { Yes }\end{array}$ & $\begin{array}{l}42(35 \%) \\
60(50 \%)\end{array}$ \\
\hline 10 & $\begin{array}{c}\text { micro leakage at IAI? } \\
\text { Are you aware of the } \\
\text { use of 'Gap seal ' at implant } \\
\text { abutment interface? }\end{array}$ & $\begin{array}{l}\text { Maybe } \\
\text { Yes } \\
\text { No }\end{array}$ & $\begin{array}{c}18(15 \%) \\
82(68.3 \%) \\
38(31.7 \%)\end{array}$ \\
\hline 11 & $\begin{array}{l}\text { Are you aware of the } \\
\text { clinical steps for using } \\
\text { 'Gap seal'? }\end{array}$ & $\begin{array}{l}\text { Yes } \\
\text { No }\end{array}$ & $\begin{array}{l}67(55.8 \%) \\
53(44.2 \%)\end{array}$ \\
\hline
\end{tabular}




\begin{tabular}{|c|c|c|c|}
\hline 12 & $\begin{array}{c}\text { Are you aware of the } \\
\text { use of '0-ring' to control }\end{array}$ & Yes & \\
\hline \multirow{3}{*}{13} & micro leakage at IAI? & No & $55(45.8 \%)$ \\
& Which according to you & Gap Seal & $73(60.8 \%)$ \\
& would be a better & 0-ring & $24(20 \%)$ \\
& sealing agent? & Others & $23(19.2 \%)$ \\
\hline
\end{tabular}

Table 2. Depicts the association of knowledge and awareness of presence of microgap and sealing agent with respect to different practitioner groups

\begin{tabular}{l|c|c|}
\hline & & \\
& & PRACTITI \\
ONER \\
GROUP
\end{tabular}

Some of the popular commercially available sealing agents include Gap seal (Hagerwerken, Duisburg, Germany), 0-ring (ORMCO, Milan, Italy), Berutemp 500 T2, Kiero Seal. An in vitro study done by Podhorsky A et al(Podhorsky et al., 2016) evaluated the influence of Kiero seal and Berutemp on bacterial colonization of the IAI, and showed a marked reduction in the bacterial cell count in comparison to the control group with no sealing agent. The efficacy of Gap seal and 0-ring was also compared in a similar study by Nayak AG et al(Nayak et al., 2014). The study showed that the leakage of the bacteria can be reduced to a negligible number by using a gel rather than an 0-ring, as its body prevents complete seating of the abutment. The rubber can deteriorate over time, which may increase leakage.

The survey showed that the dentists are moderately aware of the uses of sealing agents, and its indications. The most popular option for most of the dentists was Gap seal and they considered it slightly superior to 0-ring as was shown in the studies discussed earlier. Yet there is lack of knowledge regarding the spectrum of options available, and the clinical steps involved in their application.

Limitations: The major limitations of this study are the sample size, a larger population of dentists could have given a wider perspective and a better knowledge regarding the awareness regarding the presence of microgap and the commercially available sealing agents among dentists.

\section{CONCLUSION}

As two-piece implants are the commonly chosen treatment option by most dentists, it is essential to understand the implications of the presence of microgap at the IAI, and to take measures to prevent the consequences of microleakage. Within the limitations of the study we were able to conclude that there was average to poor awareness regarding the various sealing agents commercially available in the market, and their clinical use. Improvement in dental curriculum for the students and extended learning opportunities for the practicing dentists could increase the awareness of sealing agents and could aid in better management of the microgap at IAI.

Conflict of Interest: There is no conflict of interests.

\section{ACKNOWLEDGEMENTS}

We would like to acknowledge the staff of the Department of Prosthodontics ,Saveetha dental college and hospital for providing constant encouragement and valuable suggestions, enabling successful completion of the study.

\section{REFERENCES}

Alves, D. C. C. et al. (2016) 'In vitro analysis of the microbiological sealing of tapered implants after mechanical cycling, Clinical Oral Investigations, pp. 2437-2445. doi: 10.1007/s00784-016-1744-0.

Binon, P. P. (2000) 'Implants and components: entering the new millennium', The International journal of oral At maxillofacial implants, 15(1), pp. 76-94.

Canullo, L. et al. (2011) 'The influence of platform switching on the biomechanical aspects of the implant- 
abutment system. A three dimensional finite element study', Medicina oral, patologia oral y cirugia bucal, 16(6), pp. e852-6.

Cavalcanti, A. G. de A. et al. (2016) 'Efficacy of Gutta-Percha and Polytetrafluoroethylene Tape to Microbiologically Seal the Screw Access Channel of Different Prosthetic Implant Abutments', Clinical implant dentistry and related research, 18(4), pp. 778-787.

D’Ercole, S. et al. (2009) 'Microbiological and Biochemical Effectiveness of an Antiseptic Gel on the Bacterial Contamination of the Inner Space of Dental Implants: A 3-Month Human Longitudinal Study', International Journal of Immunopathology and Pharmacology, pp. 1019-1026. doi: 10.1177/039463200902200417.

Garrana, R. et al. (2016) 'Leakage of Microbial Endotoxin through the Implant-Abutment Interface in Oral Implants: An In Vitro Study', BioMed Research International, pp. 1-6. doi: 10.1155/2016/9219071.

Gracis, S. et al. (2012) 'Internal vs. external connections for abutments/reconstructions: a systematic review', Clinical oral implants research, 23 Suppl 6, pp. 202216.

Guerra, E. et al. (2016) 'The Impact of Conical and Nonconical Abutments on Bacterial Infiltration at the Implant-Abutment Interface', The International journal of periodontics \& restorative dentistry, 36(6), pp. 825-831.

Hagiwara, Y. and Carr, A. B. (2015) 'External versus internal abutment connection implants: a survey of opinions and decision making among experienced implant dentists in Japan', Odontology, pp. 75-83. doi: 10.1007/s 10266-013-0141-2.

Hermann, J. S. et al. (2001) 'Influence of the size of the microgap on crestal bone changes around titanium implants. A histometric evaluation of unloaded nonsubmerged implants in the canine mandible', Journal of periodontology, 72(10), pp. 1372-1383.

Koutouzis, T. et al. (2014) 'The Effect of Dynamic Loading on Bacterial Colonization of the Dental Implant Fixture-Abutment Interface: An In Vitro Study', Journal of Oral Implantology, pp. 432-437. doi: 10.1563/aaidjoi-d-11-00207.

Mangano, C. et al. (2009) 'Prospective clinical evaluation of 1920 Morse taper connection implants: results after 4 years of functional loading', Clinical Oral Implants Research, pp. 254-261. doi: 10.1111/j.16000501.2008.01649.x.

Nakahara, K. et al. (2017) 'Single-staged vs. two-staged implant placement in vertically deficient alveolar ridges using bone ring technique - Part 2: implant osseointegration', Clinical Oral Implants Research, pp. e31-e38. doi: 10.1111/clr.12851.

Nascimento, C. do et al. (2014) 'Bacterial adhesion on the titanium and zirconia abutment surfaces', Clinical oral implants research, 25(3), pp. 337-343.

do Nascimento, C. et al. (2017) 'Different sealing materials preventing the microbial leakage into the screw-retained implant restorations: an in vitro analysis by DNA checkerboard hybridization', Clinical oral implants research, 28(2), pp. 242-250.
Nayak, A. G. et al. (2014) 'Efficacy of Antibacterial Sealing Gel and 0-Ring to Prevent Microleakage at the Implant Abutment Interface: An In Vitro Study', Journal of Oral Implantology, pp. 11-14. doi: 10.1563/ aaid-joi-d-10-00167.

Olin, P. S. (2006) 'In Vitro Evaluation of the ImplantAbutment Bacterial Seal: The Locking Taper System', Yearbook of Dentistry, pp. 122-123. doi: 10.1016/s00843717(08)70106-5.

Podhorsky, A. et al. (2016) 'Bacterial Contamination of the Internal Cavity of Dental Implants After Application of Disinfectant or Sealant Agents Under Cyclic Loading In Vitro', The International journal of prosthodontics, 29(5), pp. 493-495.

Quirynen, M. et al. (1994) 'Microbial penetration along the implant components of the Branemark systemR. An in vitro study', Clinical Oral Implants Research, pp. 239-244. doi: 10.1034/j.1600-0501.1994.050407.x.

Ranieri, R. et al. (2015) 'The bacterial sealing capacity of morse taper implant-abutment systems in vitro', Journal of periodontology, 86(5), pp. 696-702.

Rismanchian, M. et al. (2012) 'Evaluation of microgap size and microbial leakage in the connection area of 4 abutments with Straumann (ITI) implant', The Journal of oral implantology, 38(6), pp. 677-685.

Sailer, I. et al. (2009) 'In vitro study of the influence of the type of connection on the fracture load of zirconia abutments with internal and external implant-abutment connections', The International journal of oral \&t maxillofacial implants, 24(5), pp. 850-858.

Seloto, C. et al. (2018) 'Efficacy of Sealing Agents on Preload Maintenance of Screw-Retained ImplantSupported Prostheses', The International Journal of Oral Et Maxillofacial Implants, pp. 123-126. doi: 10.11607/ jomi.5576.

Smith, N. A. and Turkyilmaz, I. (2014) 'Evaluation of the sealing capability of implants to titanium and zirconia abutments against Porphyromonas gingivalis, Prevotella intermedia, and Fusobacterium nucleatum under different screw torque values', The Journal of Prosthetic Dentistry, pp. 561-567. doi: 10.1016/j. prosdent.2013.11.010.

Turkyilmaz, I. et al. (2017) 'Evaluation of the Sealing Capability of the Internal Conical Connections of Implants with Titanium and Zirconia Abutments', The Journal of Contemporary Dental Practice, pp. 915-922. doi: 10.5005/jp-journals-10024-2149.

Verdugo, C. L. et al. (2014) 'Microleakage of the prosthetic abutment/implant interface with internal and external connection:In vitrostudy', Clinical Oral Implants Research, pp. 1078-1083. doi: 10.1111/ clr.12217.

Wang, Y.-C. et al. (2015) 'Marginal bone response of implants with platform switching and non-platform switching abutments in posterior healed sites: a 1-year prospective study', Clinical Oral Implants Research, pp. 220-227. doi: 10.1111/clr.12312.

World Medical Association Declaration of Helsinki: Ethical Principles for Medical Research Involving Human Subjects (2004). 